\title{
Role of dalit diaspora in the mobility of the disadvantaged in Doaba region of Punjab
}

\author{
Amanpreet Kaur
}

Authror for Correspondence:

\section{Amanpreet Kaur}

Department of Sociology, GHG Institute of Law for Women, Sidhwan Khurad, Ludhiana (Punjab) India

Email : amansoc2016@gmail. com

Received: 23.09.2019; Revised: 07.11.2019; Accepted: 21.11.2019

ABSTRACT : In Sikh majority state Punjab most of the population live in rural areas. Scheduled caste population constitute 31.9 per cent of total population. Jat Sikhs and Dalits constitute a major part of the Punjab's demography. From three regions of Punjab, Majha, Malwa and Doaba, the largest concentration is in the Doaba region. Proportion of SC population is over 40 per cent and in some villages it is as high as 65 per cent.Doaba is famous for two factors -NRI hub and Dalit predominance. Remittances from NRI, SCs contributed to a conspicuous change in the self-image and the aspirations of their families. So the present study is an attempt to assess the impact of Dalit diaspora on their families and dalit community. Study was conducted in Doaba region on 160 respondents. Emigrants and their families were interviewed to know about remittances and expenditure patterns. Information regarding philanthropy was collected from secondary sources. Emigration of Dalits in Doaba region of Punjab is playing an important role in the social mobility. They are in better socio-economic position and advocate the achieved status rather than ascribed. Majority of them are in Gulf countries and their remittances proved fruitful for their families. Eminent and wealthy NRIs contribute to the society and to make their caste more assertive i.e. politically, religiously.

KEY WORDS: Doaba, Dalits, NRIs, Remittances, Philanthropy

- HOW TO CITE THIS PAPER : Kaur, Amanpreet (2019). Role of dalit diaspora in the mobility of the disadvantaged in Doaba region of Punjab. Asian J. Home Sci., 14 (2) : 425-428, DOI: 10.15740/HAS/ AJHS/14.2/425-428. Copyright@ 2019: Hind Agri-Horticultural Society. 